\title{
EKTRAKSI BENDA ASING (KACANG TANAH) DI BRONKUS DENGAN BRONKOSKOP KAKU
}

\author{
Fachzi Fitri, M. Rusli Pulungan \\ Bagian Telinga Hidung Tenggorok Bedah Kepala Leher \\ Fakultas Kedokteran Universitas Andalas / RSUP Dr. M. Djamil Padang \\ E-mail : majalahkedokteranandalas@gmail.com
}

\begin{abstract}
Abstrak
Aspirasi benda asing merupakan keadaan emergensi yang memerlukan penanganan segera untuk mencegah komplikasi yang serius. Lebih dari 50\% kasus aspirasi benda asing terjadi pada anak usia kurang dari 3 tahun. Aspirasi benda asing paling sering adalah kacang tanah. Diagnosis ditegakkan berdasarkan anamnesis, Pemeriksaan fisik, pemeriksaan radiologi dan bronkoskopi. Bronkoskop kaku merupakan pilihan untuk pengangkatan benda asing pada anak. Dilaporkan satu kasus benda asing tiga kacang tanah di bronkus utama kanan pada seorang anak perempuan umur 2 tahun yang berhasil diangkat dengan tindakan bronkoskopi menggunakan bronkoskop kaku.
\end{abstract}

Kata kunci : Aspirasi benda asing, bronskopi, bronkoskop kaku.

\begin{abstract}
Foreign body aspiration is an emergency condition that needs early treatment to prevent serious complication. More than $50 \%$ foreign body aspiration cases occur among children younger than 3 years. The most common aspirated item was a peanut. Diagnosis is based on anamnesis, physical examination, radiology finding and bronchoscopy. Rigid bronchoscopee is a procedure of choice for removing foreign body in children.

A case foreign body (three peanuts) in the right main bronchus 2 years old girl which was successfully removed using rigid bronchoscopee was reported.

Key word : Foreign body aspiration, bronchoscopy, rigid bronchoscope
\end{abstract}




\section{Pendahuluan}

Benda asing di saluran nafas atau dikenal dengan aspirasi benda asing merupakan keadaan emergensi yang memerlukan penanganan segera. Keterlambatan penanganan dapat meningkatkan terjadinya komplikasi bahkan kematian. ${ }^{(1,2)}$ Di Amerika Serikat lebih kurang 3000 orang meninggal setiap tahunnya akibat aspirasi benda asing. ${ }^{(2-4)}$

Aspirasi benda asing dapat berupa bahan organik maupun anorganik. Bahan organik yang paling sering ditemukan adalah kacang tanah. ${ }^{(1,5,6)}$ Rina $\mathrm{MT}^{5}$ mendapatkan dari 101 kasus aspirasi benda asing organik, yang paling sering adalah kacang tanah kemu-dian dikuti biji-bjian dan tulang ayam.

Gejala klinis yang muncul bervariasi, tergantung pada derajat sumbatan, lokasi, sifat, bentuk, ukuran dan lamanya benda asing berada di saluran nafas. Diagnosis benda asing di saluran nafas ditegakkan berdasarkan gejala klinis, pemeriksaan fisik, pemeriksaan penunjang seperti Rontgen toraks maupun bronkoskopi. ${ }^{(7,8)}$

Prinsip dasar diagnosis dan penatalaksanaan terhadap aspirasi benda asing telah dikemukakan oleh Jackson and Jackson pada tahun 1936. Prinsip ini telah mengem-bangkan penggunaan endoskopi untuk mendiagnosis maupun piñata-laksanaan benda asing di trakeobronkial. ${ }^{(7)}$

Bronkoskop kaku dipakai untuk menilai secara langsung jalan nafas atas maupun jalan bafas bawah, baik untuk diagnosis benda asing maupun untuk terapinya. Komplikasi dapat terjadi akibat benda asing itu sendiri atau karena tindakan terapeutik. ${ }^{(2,5)}$

\section{Kekerapan}

Aspirasi benda asing paling banyak terjadi pada anak di bawah usia 15 tahun yaitu berkisar $75 \%-85 \%$. $^{(1)}$ lebih dari 50\% terjadi pada usia kurang dari 3 tahun. $^{(1,3,6)}$ Pada dewasa lebih sering terjadi pada usia lebih dari 50 tahun. ${ }^{7}$ Laki-laki lebih sering dibanding dengan perempuan dengan perbandingan yaitu $2: 1^{(1,4,8,9)}$

Tingginya angka kejadian aspirasi benda asing pada anak-anak karena ${ }^{\circledast 6)}$

1. Adanya kecenderungan untuk memasukkan segala sesuatu ke dalam mulut.

2. Sering anak yang menangis, berteriak, berlari dan bermain, dengan makanan di mulut

3. Gigi molar belum terbentuk sehingga proses mengunyah belum sempurna serta koordinasi proses menelan yang belum matang

Jenis aspirasi benda asing bervariasi, hal ini dipengaruhi oleh geografis, variasi makanan, maupun lingkungan. Aspirasi benda asing dapat berupa bahan organik maupun anorganik. Bahan organik yang paling sering ditemukan adalah kacang tanah. ${ }^{(1,5)}$

Yadav SPS dkk, ${ }^{(10)}$ melapor-kan aspirasi benda asing paling sering ditemukan pada anak-anak adalah kacang tanah (52,3\%), material makanan $(12,2 \%)$, biji-bijian $(5,3 \%)$, tulang $(1,5 \%)$, plastik $(15,1 \%)$, logam $(4,5 \%)$, batu $(0,8 \%)$, tablet $(1,2 \%)$ dan sisanya tidak ditemukan benda asing.

Di Departemen THT-KL FKUI RSCM Sub Departemen Bronkoesofagologi dari bulan Januari 2002 sampai Agustus 2004, tercatat 43 kasus aspirasi yang telah dilakukan tindakan bronkoskopi. Penderita terbanyak berusia di bawah 3 tahun, lebih sering pada anak laki-laki, dan kacang merupakan benda asing organik yang terbanyak. $^{(11)}$ Di Bagian THT-KL FKUA RS M. Djamil Padang selama priode Januari 2009 sampai Maret 2010 tercatat 8 kasus aspirasi benda asing yang telah dilakukan tindakan 
bronkoskopi. Sebanyak 4 kasus adalah aspirasi kacang tanah, 3 pluit mainan dan 1 kasus jarum pentul.

\section{Anatomi Traktus Traakeobronkial}

Trakea merupakan pipa yang terdiri dari tulang rawan dan otot yang dilapisi oleh epitel torak berlapis semu bersilia mulai dari kartilago krikoid sampai perca-bangan bronkus kanan dan kiri. Panjangnya kira-kira $12 \mathrm{~cm}$ pada pria dan $10 \mathrm{~cm}$ pada wanita, diameter antero posterior rata-rata 13 $\mathrm{mm}$ dan diameter transversal rata-rata $18 \mathrm{~mm}$.

Trakea terletak di tengah-tengah leher dan makin ke distal bergeser ke sebelah kanan, dan masuk ke rongga mediastinum di belakang manubrium sterni. Lumen trakea ditunjang kira-kira 18 cincin dari kartilago hialin yang tidak lengkap, di bagian posterior hanya terdiri dari otot sehingga kartilago trakea berbentuk C. Ujung terbuka tulang rawan yang berbentuk huruf $\mathrm{C}$ ini mengarah ke posterior. Di bagian posterior terdapat jaringan yang merupakan batas dengan esofagus, yang disebut dinding bersama trakeoesofagus (tracheoesphageal party wall). Cincin trakea yang paling bawah meluas ke inferior dan posterior di antara bronkus utama kanan dan kiri, membentuk sekat yang lancip di sebelah dalam yang disebut karina.

Trakea bercabang dua di setinggi torakal 4, menjadi bronkus utama kanan dan kiri. Karina letaknya lebih ke kiri dari median, sehingga lumen bronkus utama kanan lebih luas dari bronkus utama kiri. Lumen bronkus utama kanan pada potongan melintang lebih luas seperempat dari bronkus utama kiri. ${ }^{(12)}$
Bronkus utama kanan lebih pendek dari bronkus utama kiri. Masing-masing panjangnya kira-kira $2,5 \mathrm{~cm}$ dan $5 \mathrm{~cm}$ serta membentuk sudut $25^{0}$ dan sudut $45^{\circ}$ dengan garis tengah. Bronkus utama kanan hampir lurus dengan trakea sehingga benda asing eksogen yang masuk ke bronkus akan lebih mudah masuk ke bronkus utama kanan, dibanding dengan bronkus utama kiri. ${ }^{(13)}$ Sampai umur 15 tahun sudut yang dibentuk bronkus utama dengan trakea antara kiri dan kanan hampir sama. ${ }^{(6)}$

Bronkus utama kanan dan kiri akan bercabang membentuk lobus masing-masing 3 lobus dan 2 lobus. Tiap lobus bercabang lagi menjadi segmen bronkopulmoner (gambar 1).

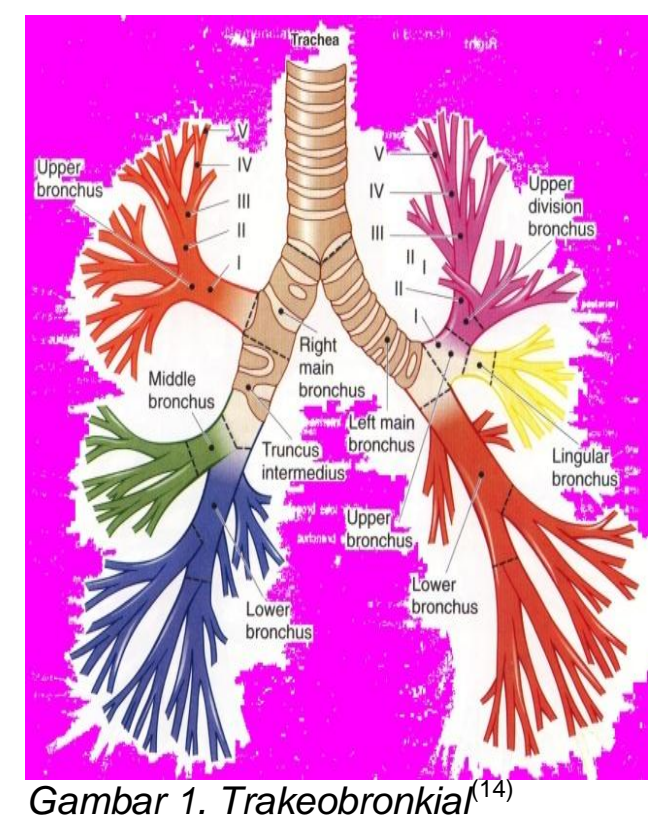

Ukuran traktus trakeobronkial pada orang dewasa antara pria dan wanita, serta pada anak-anak dan bayi berbeda. Ukuran ini terlihat pada tabel 1 sesuai dengan tabulasi Jackson. ${ }^{(14)}$ 
Tabel 1. Ukuran Trakeobronkial menurut Chevalier Jackson ${ }^{(14)}$

\begin{tabular}{lcccc}
\hline & Pria & Wanita & Anak & Bayi \\
\hline & & & & \\
D.Trakea $(\mathrm{mm})$ & $14 \times 20$ & $12 \times 16$ & $5 \times 10$ & $6 \times 7$ \\
P. trakea $(\mathrm{cm})$ & 12 & 10 & 6 & 4 \\
P. Bronkus Ka & 2,5 & 2,5 & 2 & 1,5 \\
P.Bronkus Ki & 5 & 5 & 5 & 2,5 \\
Insisivus-trakea & 15 & 13 & 10 & 9 \\
Insisivus-bronkus & 32 & 28 & 19 & 15 \\
$\quad$ Sekunder & & & & \\
\hline
\end{tabular}

\section{Patofisiologi}

Benda asing masuk ke saluran nafas saat laring terbuka atau pada saat terjadi aspirasi. Benda asing yang masuk ke saluran nafas akan mengakibatkan terjadinya reflek batuk, kemudian akan muncul gejala sesuai dengan lokasi, besarnya sumbatan dan lamanya benda asing berada di dalam saluran nafas. ${ }^{(12)}$

Benda asing yang masuk ke dalam saluran nafas akan menimbulkan reaksi pada jaringan sekitarnya. Reaksi jaringan yang timbul dapat berupa inflamasi lokal, edema, ulserasi, dan terbentuknya jaringan granulasi yang dapat mengakibatkan obstruksi jalan nafas. Akibat obstruksi ini maka bagian distal dari sumbatan akan terjadi air trapping, empisema, atelektasis, abses paru dan bronkiektasi. Reaksi inflamasi akan mengakibatkan terjadinya peningkatan vaskularisasi mukosa, edema, dan bertambahnya sekret mukoid. Berkurangnya gerakan silia mengakibatkan menumpuknya lendir atau sekret di ujung bronkiolus sehingga dapat mengakibatkan atelektasis maupun komplikasi lainnya. Bila terdapat infeksi dapat terbentuk pus serta dapat terbentuk jaringan granulasi. (1,6,11) $^{2}$

Kacang tanah merupakan benda asing organik yang bersifat higroskopis, mudah menjadi lunak dan mengembang oleh air serta menyebabkan iritasi pada mukosa. Hal ini dapat menyebabkan peradangan hebat di saluran napas dan dapat membentuk jaringan granulasi. Reaksi ini berlangsung dengan cepat. Kacang tanah dapat mengakibatkan trakeobronkitis yang berat yang disebut dengan arachidic bronchitis. Setelah masa laten kira-kira 24 jam akan timbul gejala batuk dengan sputum yang purulen dan disertai demam. ${ }^{(12,13)}$

\section{Gejala Klinis}

Gejala klinis yang timbul akibat aspirasi benda asing pada saluran napas berbeda pada masing-masing pasien tergantung dari ukuran, bentuk, sifat benda asing, lamanya benda asing di dalam saluran napas, dan lokasi benda asing berada. ${ }^{(12)}$

Bila seorang pasien, terutama pada anak, diketahui mengalami rasa tercekik atau manifestasi lainnya seperti rasa tersumbat di tenggorok, batukbatuk sedang makan, maka keadaan ini dianggap sebagai gejala aspirasi benda asing.

Gejala yang paling sering ditemukan adalah adanya riwayat memasukkan benda asing ke dalam mulut kemudian tersedak (85\%), batuk yang paroksismal (59\%), nafas berbunyi (57\%) dan sumbatan jalan nafas yang nyata $(5 \%)$. Gejala lain yang muncul adalah demam, batuk berdarah, pneumotoraks. ${ }^{(7)}$

Pada pemeriksaan fisik sering ditemukan tidak adanya kelainan atau asimtomatis (40\%), wheezing (40\%) penurunan suara nafas pada sisi terdapatnya benda asing $(5 \%) .^{7}$ Pada sumbatan jalan nafas yang nyata dapat ditemukan sianosis. ${ }^{(8)}$

Gejala aspirasi benda asing terbagi dalam 3 fase yaitu $:^{(11,15,16)}$

* Fase awal

Saat benda asing teraspirasi, batuk secara tiba-tiba, rasa tercekik, rasa tersumbat di tenggorok, wheezing dan obstruksi nafas, dapat juga disertai 
adanya sianosis terutama perioral, kematian pada fase ini sangat tinggi

* Fase asimptomatik

Interval bebas gejala terjadi karena benda asing tersangkut pada satu tempat, dapat terjadi dari beberapa menit sampai berbulan-bulan setelah fase awal. Lama fase ini tergantung lokasi benda asing, derajat obstruksi yang ditimbulkannya dan jenis benda asing yang teraspirasi serta kecenderungan benda asing untuk berubah posisi

* Fase komplikasi

Telah terjadi komplikasi obstruksi dan atau infeksi. Gejala dapat berupa demam, pneumonia, atelektasis, abses paru dan hemoptisis.

Obstruksi beronkus menurut Jackson\&Jackson seperti dikutip Tamin $\mathrm{S} \mathrm{dkk},{ }^{(1)}$ dibagi dalam 4 tipe yaitu:

1. Sumbatan sebagian dari bronkus (by pass valve obstruction)

2. Sumbatan pentil dengan ekpirasi yang terhambat (expiratory check valve obstruction)

3. Sumbatan pentil dengan inspirasi yang terhambat (inspiratory check valve obstruction )

4. Sumbatan total (stop valve obstruction )

\section{Pemeriksaan Radiologi}

Pada kebanyakan kasus aspirasi pada anak-anak, benda asing bersifat radiolusen dan hanya $7 \%$ yang bersifat radioopak. Oleh karena itu pemeriksaan radiologi terutama berguna untuk mendeteksi gejala yang ditimbulkan oleh benda asing tersebut. ${ }^{(6,11)}$

Pada 24 jam pertama sering pemeriksaan radiologi tidak menunjukkan kelainan., 1,6,11 Gambaran radiologi yang dijumpai dapat berupa gambaran normal, air trapping, atelektasis, pneumonia, kolaps paru, konsolidasi dan benda asing radioopak. ${ }^{(6,11)}$

Kaur dkk dikutip Tamin $\mathrm{S}$ dkk ${ }^{11}$ melaporkan hasil Rontgen toraks pada aspirasi benda asing didapatkan gambaran paru normal 32\%, kolaps paru $32 \%$, pergeseran mediastinum $20 \%$, konsolidasi $20 \%$, empisema $16 \%$, dan benda asing radioopak $6 \%$. Giannoni $\mathrm{CM}^{7}$ mendapatkan hasil Rontgen toraks normal 10\% - 20\%, atelektasis $22 \%$, pneumonia $20 \%$, benda asing radioopak 13\%, pada kasus aspirasi benda asing.

\section{Diagnosis}

Diagnosis adanya benda asing di saluran nafas ditegakkan dengan melakukan anamnesis yang teliti terhadap pasien maupun saksi yang melihat kejadian, namun sering tidak terdapat saksi yang melihat dan penderita yang belum bisa menceritakan keajadian yang dialaminya. Anamnesis yang khas untuk aspirasi seperti batuk yang paroksismal, mendadak sesak nafas berbunyi atau kebiruan di sekitar mulut, ditemukan lebih dari $90 \%$ kasus. ${ }^{(11)}$

Benda asing di bronkus akan menyebabkan gejala seperti batuk yang pada awalnya tidak produktif menjadi produktif, sesak nafas, sianosis, dan terdapat retraksi. ${ }^{(11)}$

Pemeriksaan fisik maupun pemeriksaan radiologi dilakukan untuk menentukan adanya benda asing, lokasi benda asing dan kelainan yang ditimbulkannya. Namun tidak jarang pemeriksaan fisik maupun pemeriksaan radiologi tidak memperlihatkan adanya kelainan. $^{(7,11,15)}$

Pada kasus dengan anamnesis dan pemeriksaan fisik serta pemeriksaan radiologi yang mencurigakan suatu aspirasi benda asing, maka tindakan bronkoskopi 
dilakukan untuk diagnosis banding. ${ }^{(11)}$

\section{Penatalaksanaan}

Prinsip penatalaksanaan benda asing di saluran nafas adalah mengeluarkan benda asing dengan segera dalam kondisi maksimal dan trauma yang minimal. Penentuan cara pengambilan benda asing dipengaruhi oleh beberapa faktor, yaitu usia penderita, keadaan umum, lokasi, jenis benda asing dan lamanya benda asing berada di saluran nafas.

Benda asing di bronkus dapat dikeluarkan dengan menggunakan bronkoskop kaku maupun dengan bronkoskop serat optik. Angka keberhasilan pengangkatan benda asing di saluran nafas mencapai $91,3 \% .^{(17)}$ Pada bayi dan anak yang diameter jalan nafasnya relatif kecil dipakai bronkoskop kaku untuk dapat mempertahankan patensi nafas dan pemberian oksigen. ${ }^{(6,11,17,18)}$

Sebelum tindakan bronkoskopi dilakukan, sebaiknya diusahakan memperoleh duplikat benda asing tersebut. Kemudian dicoba dan dipelajari cara menjepit dan menarik benda asing dengan cunam yang sesuai. Pemilihan bronkoskop yang sesuai dengan diameter lumen, berpedoman pada usia penderita disertai persiapan bronkoskop dengan ukuran yang lebih kecil akan dapat meningkatkan angka keberhasilan. ${ }^{(11)}$

Sesaat menjelang dilakukan bronkoskopi dibuat foto toraks untuk menilai kembali letak benda asing. Komunikasi antara operator dengan ahli anestesi untuk menentukan rencana tindakan juga sangat penting. ${ }^{(11)}$

Pemberian steroid dan antibiotika pre operatif dapat mengurangi komplikasi seperti edema jalan nafas dan infeksi. ${ }^{(11,18)}$ Antibiotik dan steroid tidak rutin diberikan sebelum tindakan bronkoskopi, hanya pada kasus yang terlambat dalam diagnosisnya dan pada benda asing organik. $^{(11)}$

Tindakan bronkoskopi yang dilakukan dalam penanganan aspirasi benda asing berdasarkan jenis, lokasi tersangkutnya, dan derajat obstruksi yang terjadi, dapat dibagi atas $:^{(11)}$

1. Bronkoskopi darurat yaitu tindakan bronkoskopi yang segera dilakukan pada saat diagnosis ditegakkan.

2. Bronkoskopi segera yaitu tindakan bronkoskopi dilakukan sesegera mungkin setelah alat, pasien dan tim bronkoskopi siap secara optimal.

3. Bronkoskopi elektif yaitu tindakan bronkoskopi dilakukan secara terencana dengan persiapan sempurna.

\section{Bronkoskop Kaku}

Bronkoskop kaku berbentuk tabung logam dengan sumber cahaya di bagian proksimal. Ukuran dia-meter serta panjang tabung bermacam-macam disesuaikan dengan penampang bronkus yang akan diperiksa.

Bronkoskop kaku dipilih pada kondisi: ${ }^{(18)}$

- Kasus-kasus pediatrik dimana rima glotis dan trakea masih kecil.

- Perdarahan paru yang masif oleh karena daya isap nya lebih besar atau mungkin diperlukan pemasangan tampon.

- Drainase abses paru yang pecah.

- Sumbatan bronkus dengan sekret liat atau cukup banyak.

- Pengambilan benda asing jika terletak di trakea atau bronkus utama.

- Untuk fotografi sepanjang masih bisa dilihat dengan teleskop.

- Trakea yang sempit. 
Keuntungan Bronkoskop kaku(18)

- Pernafasan lebih terkontrol

- Kualitas cahaya baik

- Lumen lebih besar sehingga memudahkan untuk melihat jelas, mengatsi perdarahan masif dan pengangkatan benda asing

Sebaiknya bronkoskop kaku tidak digunakan pada kasus dengan aneurisma aorta, kecenderungan perdarahan, keadaan fisik yang lemah setelah hemoptisis berat dan gangguan fungsi jantung paru yang berat. ${ }^{(18)}$

\section{Bronkoskop Serat Optik}

Bronkoskopi serat optik atau flexible broncho fibroscope sesuai dengan namanya adalah bronkoskop yang lentur. Terdiri dari berbagai macam ukuran dengan diameter luar 3,4 $\mathrm{mm}$ sampai 5,9 $\mathrm{mm}$. Sumber cahaya dari cold light dengan intensitas tinggi yang dihantarkan lewat kabel ganda dalam bentuk glass fiber ke bronkoskop yang diteruskan ke bagian distal. Pada ujung distal $\pm 5 \mathrm{~cm}$ sangat fleksible dan dapat bergerak dalam bentuk bidang yaitu ke atas 130 dan ke bawah $130^{\circ}$ atau ke atas $180^{\circ}$ dan ke bawah $60^{\circ} .{ }^{(12,19)}$

Alat ini dilengkapi dengan lensa yang tajam, dengan jarak ketajaman 3$50 \mathrm{~mm}$. Disamping itu masih ada 2 lubang untuk keluar cahaya yang cukup untuk melihat dan membuat foto. Terdapat satu channel dimana dapat digunakan untuk mengisap atau tempat masuknya alat-alat seperti, forcep biopsi, forcep untuk benda asing, atau memasukkan cairan anestesi. Bronkoskopi serat optik dipilih pada: ${ }^{(19)}$

- Trakea dan bronkus dengan diameter lebih besar, paling sedikit $2 \mathrm{~mm}$ lebih besar dari pada diameter bronkoskopi serat optik.
- Keperluan diagnosis dan terapi pada batuk kronis atau riwayat hemoptisis.

- Biopsi kelainan paru.

- Mengisap sekret terutama dari bronkus segmen.

- Penderita dengan trauma atau patah pada rahang, tulang leher, tengkorak, laring, dan trakea.

\section{Tabel 2. Ukuran bronkoskop sesuai} usia $^{(20)}$

\begin{tabular}{ll}
\hline Usia & Ukuran Bronkoskop \\
\hline Prematur & $3,0 \mathrm{~mm} \times 20 \mathrm{~cm}$ \\
Bayi & $3,5 \mathrm{~mm} \times 25 \mathrm{~cm}$ \\
$3-6$ bulan & $3,5 \mathrm{~mm} \times 30 \mathrm{~cm}$ \\
1 tahun & $4,0 \mathrm{~mm} \times 30 \mathrm{~cm}$ \\
2 tahun & $4,0 \mathrm{~mm} \times 30 \mathrm{~cm}$ \\
4 tahun & $5,0 \mathrm{~mm} \times 35 \mathrm{~cm}$ \\
$5-7$ tahun & $5,0 \mathrm{~mm} \times 35 \mathrm{~cm}$ \\
$8-12$ tahun & $6,0 \mathrm{~mm} \times 35 \mathrm{~cm}$ \\
& $7,0 \mathrm{~mm} \times 40 \mathrm{~cm}$ \\
\hline
\end{tabular}

\section{Teknik Bronkoskopi Kaku}

Bronkoskopi dengan mengguna-kan bronkoskop kaku dilakukan dalam anestesi umum. Ada dua variasi teknik intubasi bronkoskop tergantung pada keterampilan ahli bronkoskopi, anatomi dan keadaan klinis pasien yaitu: ${ }^{(21)}$
1. Teknik intubasi tanpa laringoskop
2. Teknik intubasi dengan laringoskop

Cara yang dipilih harus didiskusikan dengan ahli anastesi, termasuk risiko anestesi. Pada kasus ini menggunakan teknik ke-2.

Posisi kepala penderita tidur terlentang dengan posisi kedua lengan terletak datar sepanjang sisi badan. Kepala dan mata ditutup dengan kain. Seorang asisten duduk disebelah kiri 
memegang dan mengatur posisi kepala. Saat memasukkan laringoskop kepala fleksi untuk dapat melihat epiglotis. Setelah tampak epiglotis, dasar lidah diangkat dengan spatula laringoskop, sehingga epiglotis sedikit terangkat. Bronkoskop dipegang dengan tangan kanan dan ujung bronkoskop dimasukan di bawah epiglotis, asisten memposisikan kepala ekstensi sedikit demi sedikit sesuai dengan posisi bronkoskop. Setelah terlihat pita suara bronkoskop dimasukkan dan pandangan beralih dari laringoskop ke bronkoskop. Bronkoskop dimasukan ke laring bersamaan dengan mengeluarkan laringoskop. Ujung bronkoskop harus berjalan di antara kedua pita suara dengan memutar bronkoskop $90^{\circ}$ searah jarum jam. Setelah memasuki trakea bronkoskop diputar kembali $90^{\circ}$, sehingga ujung bronkoskop kembali mengarah ke anterior. Trakea dievaluasi dan sekret dihisap, jika memilliki kamera dapat dipasang, sehingga gambaran endoskopi dapat dilihat dengan monitor. Bronskoskop diteruskan ke distal sampai karina. Untuk memasuki bronkus kanan kepala pasien diputar sedikit ke kiri, bronkoskop diteruskan dengan gerakan membelok melalui karina. Untuk memasuki bronkus kiri kepala pasien diputar ke arah bahu kanan. Pada saat benda asing terlihat sekret yang ada disekitarnya dihisap dan dilakukan pengangkatan benda asing dengan cunam yang sesuai. Mengeluarkan bronkoskop selalu dilakukan dengan melihat lumen dengan hati-hati dan gerakan bronkoskop mengikuti gerakan saat masuk, bronkoskop berhenti beberapa millimeter di atas karina menunggu pernafasan spontan, kemudian ekstubasi dengan sekali gerakan (one single movement). Sekret tenggorok dihisap secara hati-hati dengan bantuan laringoskop, mandibula diangkat untuk membantu pernafasan spontan, sekret di hidung dihisap dan menunggu pasien batuk. ${ }^{(18,21)}$

\section{Komplikasi}

Komplikasi yang mungkin terjadi pada aspirasi benda asing di trakeobronkial berhubungan dengan benda asing sendiri dan tindakan bronkoskopi. Komplikasi akibat benda asing yang paling sering adalah infeksi paru dan kelainan lain

seperti edema, tracheitis, bronkitis atau timbulnya jaringan granulasi, dan atelektasis. $^{(11,12)}$

Komplikasi yang berhubungan dengan tindakan bronkoskopi, Lukomsky seperti dikutip Mangape $\mathrm{D}^{(18)}$ terdiri dari :

- Komplikasi mayor ; tension pneumotoraks, perdarahan hebat, hipoksia berat, gagal jantung.

- Komplikasi minor; perlukaan mukosa faring, laringitis akut, hifoksia, perdarahan sedang, demam.

Komplikasi setelah bronkoskopi paling sering adalah pneumonia, walupun secara absolut kejadiannya rendah berkisar $2,9 \%$. $^{(2)}$

\section{Prognosis}

Hampir seluruh benda asing di saluran nafas dapat diangkat dengan bronkoskopi. Komplikasi akan meningkat jika diagnosis maupun penatalaksanaan dilakukan setelah 24 jam kejadian. Tidak cukup data untuk mengatakan berapa lama benda asing di dalam saluran nafas sehingga tidak dapat diangkat dengan bronkoskopi. ${ }^{\left({ }^{3}\right)}$

\section{Laporan Kasus}

Seorang anak perempuan umur 2 tahun datang ke IGD RS. Dr. M. Djamil Padang pada tanggal 25 September 2009 jam 04.50 WIB, 
diantar oleh keluarga dengan keluhan sesak nafas sejak 12 jam yang lalu. Dari anamnesis didapatkan bahwa penderita tersedak kacang tanah 3 hari yang lalu. Sebelumnya pasien sedang makan kacang tanah, tiba-tiba terjatuh dan menangis, sehingga tersedak kacang tanah yang berada di dalam mulutnya. Pasien batuk dan terlihat sesak nafas. Kemudian sesak nafas hilang sendiri setelah beberapa saat. Tidak ada kesulitan menelan, tidak ada demam, tidak ada keluar darah dari mulut maupun dari hidung. Sesak nafas muncul kembali sejak 12 jam sebelum masuk rumah sakit.

Pada pemeriksaan fisik didapatkan keadaan umum sakit sedang, sadar, nafas 32x/menit, nadi 76x/menit, suhu $36,5^{\circ} \mathrm{C}$. Tidak ada sianosis. Respirasi; gerakan dada simetris kiri dan kanan, tidak ada retraksi, stridor tidak ada. Suara nafas bronkovesikuler, suara nafas sebelah kanan sama dengan kiri, rhonki (-), wheezing (-). Krepitasi pada leher maupun dada tidak ada. Pada telinga, hidung maupun tenggorok tidak ditemukan kelainan. Ditegakkan diagnosis kerja suspek benda asing (kacang tanah) di bronkus.

Pemeriksaan Rontgen toraks dalam batas normal, tidak ditemukan adanya bayangan radioopak (gambar
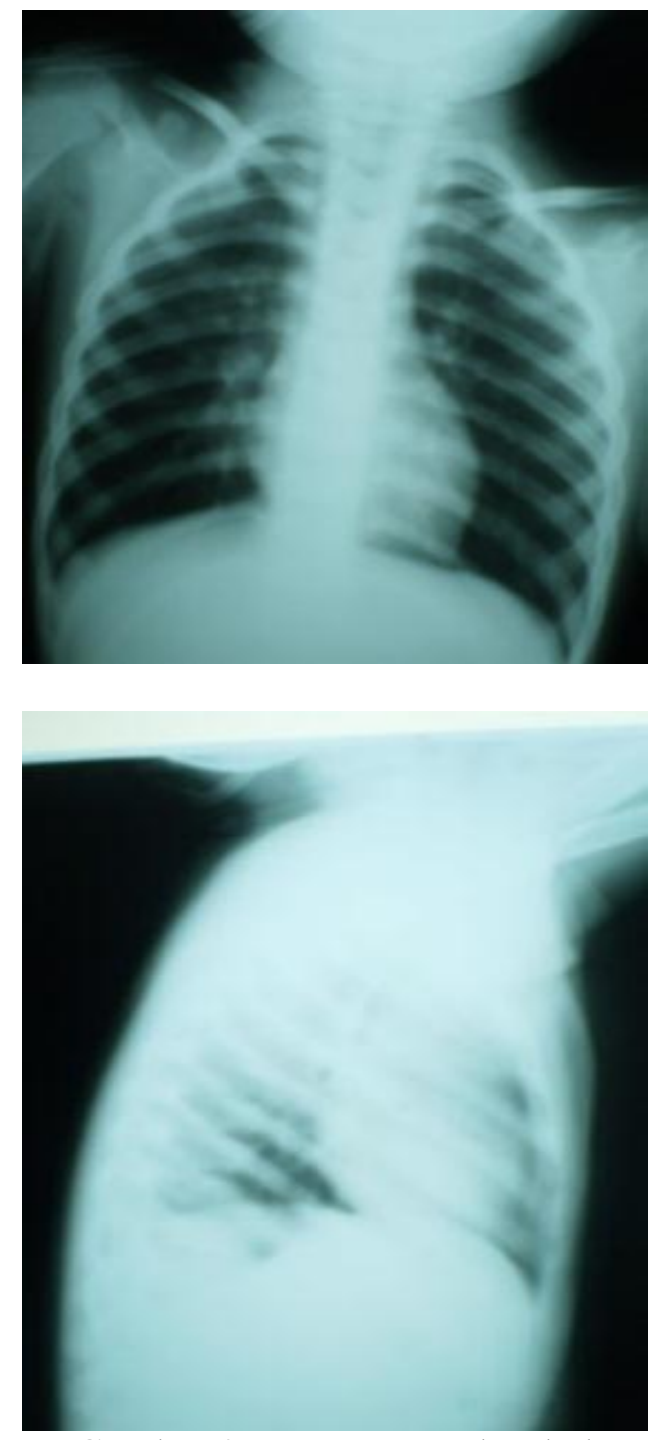

Gambar 2. Rontgen torak sebelum operasi. $2)$. 
Hasil pemeriksaan laboratorium; hemoglobin $12,0 \mathrm{gr} \%$, leukosit 12.100 $/ \mathrm{mm}^{3}$, hematokrit $36 \%$, trombosit $529.000 / \mathrm{mm}^{3}$, waktu pembekuan 5 menit 20 detik (regensia untuk pemeriksaan PT/APTT habis). Ditegakkan diagonsis suspek benda asing (kacang tanah) di bronkus.

Direncanakan untuk dilakukan bronkoskopi dengan menggunakan bronkoskop kaku dalam anestesi umum untuk diagnosis dan terapi. Dilakukan persiapan tindakan, konsultasi dengan bagian Ilmu Kesehatan Anak untuk toleransi tindakan dan konsultasi ke bagian Anestesi. Diberikan Deksametason (iv) 3 x 2,5 mg dan Ceftriaxon (iv) 1 x $750 \mathrm{mg}$ (skin test). Rontgen toraks diulang 1 jam sebelum tindakan bronkoskopi. Kesan tidak ada kelainan dan tidak terlihat benda asing di saluran nafas.

Bronkoskopi dilakukan pada tanggal 25 September 2009 mulai jam 13.00 WIB berakhir pukul 15.00 WIB. Laporan operasi adalah sebagai berikut:

1. Penderita tidur telentang di meja operasi dalam narkose umum, kepala dipegang oleh asisten dengan posisi fleksi. Laringoskop lurus dimasuk-kan sampai terlihat epiglotis.

2. Dasar lidah diangkat dan terlihat laring. Bronkoskop ID $4 \mathrm{~mm}$ panjang $30 \mathrm{~cm}$ dipegang dengan tangan kanan, ujung bronkoskop dimasukkan sedikit di bawah epiglotis, pandangan pindah ke bronkoskop dan dimasuk-kan melewati laring ber-samaan dengan mengeluar-kan

laringoskop, kepala diekstensikan perlahan-lahan sesuai dengan masuknya bronkoskop.

3. Bronkoskop dimasukkan menelusuri trakea sekret dihisap, tidak terlihat benda asing di trakea, tidak terlihat adanya kelainan di trakea.

4. Bronkoskop diteruskan ke karina terlihat benda asing kacang di bronkus utama kanan, menutupi setengah bronkus utama kanan.

5. Dengan cunam peanut, kacang tanah dijepit, diangkat keluar.

6. Bronkoskop di tarik sedikit di atas karina untuk memberi-kan respirasi yang optimal.

7. Dilakukan evaluasi terlihat benda asing kacang tanah di bronkus utama kanan.

8. Benda asing diangkat dengan cunam peanut.

9. Dilakukan lagi evaluasi dan terlihat benda asing kacang tanah ke tiga di bronkus utama kanan.

10. Diangkat dengan cunam peanut.

11. Bronkoskop dikeluarkan sambil melakukan evaluasi.

12. Bronkoskop dimasukkan kembali dan dilakukan evaluasi tidak ditemukan adanya benda asing baik di bronkus kanan maupun bronkus kiri, mukosa bronkus utama kanan hiperemis, tidak ada laserasi, sedikit edema.

13. Bronkoskop dikeluarkan, operasi selesai, dengan berhasil mengeluarkan benda asing 3 keping kacang tanah (kacang tojin).

Pada laporan anestesi selama operasi diberikan deksamethason injeksi 5mg, disamping obat anestesi.

Pasien dirawat di bangsal THT, diberi terapi ceftriaxone $1 \times 750 \mathrm{mg} \mathrm{IV}$, parasetamol sirup $3 \times 120 \mathrm{mg}$, deksametason IV $3 \times 2,5 \mathrm{mg}$, bromheksin $3 \times 2 \mathrm{mg}$. Pasien diobservasi selama 24 jam pasca tindakan, tidak ada keluhan sesak nafas, batuk berdahak ada, demam tidak ada, tidak terdapat krepitasi maupun tanda-tanda 
pneumotoraks. Rontgen toraks tanggal 28 September pasca tindakan, tidak ditemukan adanya kelainan di paru. Pasien dipulangkan setelah 5 hari pasca tindakan disertai pemberian antibiotika peroral.

\section{Diskusi}

Telah dilaporkan satu kasus aspirasi benda asing (kacang tanah) di bronkus utama kanan pada seorang anak perempuan umur 2 tahun. Kasus ini sesuai dengan berbagai literatur bahwa kejadian aspirasi benda asing 75\%-85\% terjadi pada anak usia kurang 15 tahun $^{1}$. Lebih $50 \%$ terjadi pada anak kurang dari 3 tahun. ${ }^{(1,3)}$ Anak dengan pertumbuhan gigi molar yang belum sempurna, koordinasi menelan yang belum matang dan makanan berada dalam mulut saat terjatuh dan menangis merupakan faktor penyebab terjadinya aspirasi benda asing pada kasus ini.

Pada kasus ini aspirasi benda asing adalah kacang tanah. Yadav SPS $\mathrm{dkk},{ }^{10}$ mengatakan benda asing paling banyak ditemukan pada anak-anak adalah kacang tanah $(52,3 \%)$, material makanan $(12,2 \%)$, biji-bijian $(5,3 \%)$, tulang $(1,5 \%)$, plastik $(15,1 \%)$, logam $(4,5 \%)$, batu $(0,8 \%)$, tablet $(1,2 \%)$ dan sisanya tidak ditemukan benda asing. Rina $\mathrm{TM},{ }^{5}$ aspirasi benda asing terbanyak adalah, kacang tanah, diikuti biji-bijian, dan tulang ayam.

Gejala awal pada pasien ini adalah adanya riwayat tersedak yang diikuti oleh batuk-batuk dan sesak nafas, tidak ada laporan pemeriksaan fisik pada saat ini karena gejala hilang setelah beberapa lama, sehingga keluarga tidak memeriksa-kan pasien. Giannoni $\mathrm{MC}^{(7)}$ mendapatkan gejala awal pada aspirasi benda asing adalah adanya riwayat tersedak $85 \%$, batuk yang paroksismal $57 \%$, wheezing $57 \%$, sumbatan jalan nafas $5 \%$. Fase asimtomatis selama 2 hari lalu diikuti fase komplikasi berupa sesak nafas. Komplikasi pada kasus aspirasi benda asing sangat tergantung jenis, ukuran dan letak benda asing berada. ${ }^{(12)}$

Kacang tanah merupakan benda asing organik yang dalam waktu cepat dapat mengakibatkan terjadinya peradangan sehingga terjadi edema maupun trakaeo-bronkitis. Setelah 24 jam masa laten akan memberikan gejala batuk dengan sekret yang purulen. ${ }^{(12,13)}$ Benda asing pada pasien ini sudah 3 hari, namun saat bronkoskopi tidak ditemukan adanya reaksi inflamasi maupun sumbatan yang berarti, ini mungkin karena kacang yang ada pada kasus ini adalah kacang tojin dimana kacang ini tidak mengandung kulit dan sifat higroskopisnya sudah berkurang karena sudah direndam kemudian digoreng. Juga telah diberikan kortikosteroid 6-7 jam sebelum operasi, dan selama operasi.

Pemberian antibiotik dan steroid sangat berguna pada kasus yang terlambat dalam diagnosis dan pada benda asing organik untuk mengurangi edema sebelum tindakan bronkoskopi. Antibiotik untuk mengatasi maupun mencegah infeksi yang mungkin terjadi akibat aspirasi benda asing. Steroid yang diberikan biasanya deksametason atau metil prednisolon suksinat secara intravena.

Diagnosis benda asing di saluran nafas baru ditegakkan pada hari ke tiga. Benda asing di saluran nafas sering mengalami keterlam-batan diagnosis karena adanya fase asimtomatis. Kim dkk dikutip Giannoni MC $^{(7)}$ melaporkan benda asing di saluran nafas didiagnosis pada hari 0-1 adalah $45 \%$, hari ke 2-7 adalah $22 \%$ hari ke $7-30$ adalah $14 \%$ dan setelah hari ke 30 adalah $17 \%$.

Pemeriksaan Rontgen toraks pada kasus ini tidak ditemukan adannya 
kelainan. Giannno $\mathrm{MC}^{7}$ mengatakan pemeriksaan dengan Rontgen toraks 10$20 \%$ dalam batas normal. Rina MT, ${ }^{(5)}$ pemeriksaan Rontgen toraks memberikan gambaran yang abnormal $67 \%-80 \%$.

Pada pasien ini dilakukan tindakan bronkoskopi segera dengan menggunakan bronkoskop kaku untuk diagnosis pasti dan sekaligus mengeluarkan benda asing. Bronkoskop kaku merupakan pilihan terbaik untuk kasus anak, karena dapat menjamin patensi jalan nafas dan visualisasi yang baik. ${ }^{(6,11,17,18)}$

Kesulitan saat ekstraksi pada pasien ini disebabkan adanya tiga keping kacang tanah, sehingga bronskop harus berada di saluran nafas lebih dari 20 menit. Lore dan Medina, ${ }^{(20)}$ pemakaian instrument bronkoskoskopi di saluran nafas sedapat mungkin tidak lebih dari 20 menit. Waktu yang lama dalam tindakan bronkoskopi dikuatirkan meningkatkan komplikasi. Lukomsky dikutip Mangape $\mathrm{D}^{(18)}$ mengatakan komplikasi tindakan bronkoskopi terbagi 2:

a). Komplikasi minor berupa perlukaan mukosa faring, laringitis akut, hipoksia, perdarahan sedang dan demam.

b). Komplikasi mayor berupa tension pneumothorak, perdarahan hebat, hipoksia berat sampai kegagalan jantung. Dari gejala klinis, pemeriksaan fisik dan Rontgen toraks pasca operasi tidak ditemukan adanya komplikasi.

\section{KEPUSTAKAAN}

1. Dikensoy O, Usalan C, Filiz A. Foreign body aspiration: Clinical utility of flexible bronchoscopy. Postgrad Med J 2002; 78: 399-403.
2. Saki N, Nikakhlagh S, Rahim F, Abshirini H. Foreign body aspiration in infancy: A 20-year experience. Int J. Med. Sci 2009; 6: 322-8.

3. Nagendran T. Management of foreign bodies in the emergency departement. Hospital Phisician September, 1999: 27-40.

4. Rahbarimanesh A, Noroozi E, Molaian M, Salamati P. Foreign body aspiration: A five-year report in a Children's Hospital. Iran J pediart 2008; 18: 190-2.

5. Rina MT, Quintos R. Pediatric rigid bronchoscopy for foreign body removal. Phillipp J Otolaryngol Head Neck Surg 2009; 24 (1): 39-41.

6. Rovin JD, Rodgres BM. Pediatric foreign body aspiration. Ped in review 2000; 21: 86-90.

7. Giannomi MC. Foreign body aspiration. Available from: www.BCM.edu/oto/grand/com. Up date march 10, 1994. Accessed January 24, 2010.

8. Warshawsky ME. Foreign body aspiration. Available From: www.emedicine.com. Update: Juni 3, 2008. Accessed January $20,2010$.

9. Iskandar N. Ingested and inhaled foreign bodies in Dr. Cipto Mangunkusumo Hospital, Jakarta. Med J ORLI 1994; 25: 311-8.

10. S Yadap SP, J Singh, N Aggarwal, A Goel. Airway 
foreign bodies in children:

Experience of 132 cases. Singapore Med J 2007; 48( 9): 850-3.

11. Tamin S, Hadjat F, Abdillah F. Penatalaksanaan aspirasi benda trakeobronkial bengan berbagai manifestasi klinis. Med J ORLI 2005; 35: 16-25.

12. Snow $\mathrm{JB}$,

Jr.

Bronchoesofagology. In : Ballenger JJ, editor. Disease of the nose, throat, ear head and neck. $13^{\text {th }}$ ed. Philadelphia: Lea \& Febiger; 1996. p.1331-67.

13. Iskandar N. Bronkoskopi. Dalam: Soeperdi EA, Iskandar N, Bashiruddin J, Restuti RD. editors. Buku ajar ilmu kesehatan telinga hidung tenggorok kepala dan leher. Eds 6. Jakarta FKUI; 2007.p.266-76.

14. Jackson C, MD., SCD., LL.D. Bronchoesophagology. In: Bronchoesophagology.

Phyladelphia and London; 1958. p. 5-34.

15. Kirby MT. Foreign bodies of the airway and esophagus. Available from:www.BCM.edu/oto/grand. com. Update: September 19, 2002. Accessed January 24, 2010.
16. Freiman MA. Unique presentation of a bronchial foreign body in an asymptomatic child. Ann Otol Rhinol laryngol 2001; 110: 4957.

17. Jabbardarjani HR, Kiani A, Arab A. Removal of impacted foreign body by bronchoscopic modalities. Tanaffos 2009; 8: 4: 60-4.

18. Mangape D, Asbudi. Bronkoskopi kaku. Dalam: Lokakarya Endoskopi, Ujungpandang. Desember 1987. p. 8-29.

19. Cosal ID, Imran Ali. Penggunaan bronkoskopi serat optik dalam diagnosis dan pengobatan kelainan trakeobronkial. Dalam: Lokakarya Endoskopi, Ujungpandang. Desember 1987.p. 30-60.

20. Leighton GS, Penyakit jalan nafas bagian bawah dan mediastinum: Pertimbangan endoskopi. In: Adam boies, editor. Buku ajar penyakit THT. Edisi 6. Jakarta 1997. p. 454472.

21. Lore JM and Medina JE. Rigid bronchoscopy. In: Lore and Medina, editors. An atlas of head and neck surgery. $4^{\text {th }}$ ed. Elsevier Saundres; 2005. p.18892. 